\title{
Inhalt, Vol. 2, No. 6, 1979
}

\section{Contents}

Impressum Ill

HILDENBRAND, G.; BAUR, M. P. und HILLDENBRAND, K.,

Bonn

Berücksichtigung der Aufklärungspñicht bei Therapie-

studien und ihre Auswirkung auf Randomisierungs- und

Auswertungsverfahren

221

Gruber, F.O. und Sag aster, P., Wien

Generalrehabilitation in der Onkologie 226

Aulbert, E.; Wenig, H. G.; Kubassi, F. und

Gericke, D., Berlin

Zur Anämie bei malignen Tumoren - Der Verlust von

zirkulierendem Transferrin durch lysosomale Speiche-

rung in malignen Tumoren des Menschen und der Ratte . 230

Urban, Ch.; Mutz, I.; Kotz, R. und Krisch, K.,

Graz und Wien

Management der akuten Toxizität nach hochdosierter

Methotrexatbehandlung

238

Freund, M.; Ostendorf, P. und Waller, H. D.,

Tubingen

Meningeosis carcinomatosa bei Patientinnen mit Mam-

makarzinom 243

Buchbesprechungen 248

Degrell, I., Zalaegerszeg

Gynäkomastie als Präkarzinom: Ergebnisse der Punk-

tionszytologie und Histologie 249

Fladerer, H. P., Wien

Die Diagnose von Pankreatitis und Pankreaskarzinom

durch intraoperative Feinnadelaspirationszytologie ... 253

Tautz, Chr.; Schieferstein, G. und Haag, M.,

Tubingen

Der Elektrophorese-Mobilitäts-(EM-) und der Rosetten-

Test bei malignem Melanom und bei Psoriasis vulgaris . . 256

Onkologie-Mitteilungen 261

Imprint HI

Hildenbrand, G.; Baur, M. P., and Hildenbrand, K.,

Bonn

Informed Consent in Clinical Trials and its Impact on 
Methods of Randomization and Statistical Evaluation . . 221

Gruber, F. O. and Sagaster, P., Vienna

General Rehabilitation in Oncology 226

Aulbert, E.; Wenig, H. G.; Kubassi, F., and

Gericke, D., Berlin

The Uptake of Transferrin by Tumor Cells as a Causal

Factor for the Anemia in Malignant Diseases in Man and

in the Rat 230

Urban, Ch.; Mutz, I.; Kotz, R., and Krisch, K.,

Graz and Vienna

Management of Acute Toxicity after High Dose Metho-

trexate Therapy 238

Freund, M.; Ostendorf, P., and Waller, H. D.,

Tubingen

Meningeal Carcinomatosis in Patients with Breast Cancer 243

Book Reviews 248

Degrell, I., Zalaegerszeg

Gynecomastia as Precancerous Lesion: Aspiration Biopsy

Cytology and its Histology 249

Fladerer, H. P., Vienna

Diagnosis of Pancreatitis and Pancreatic Carcinoma by

Means of Intraoperative Fine Needle Aspiration Biopsy . 253

Tautz, Chr.; Schieferstein, G., and Haag, M.,

Tubingen

Electrophoretic Mobility Test and Rosette Formation

Test in Malignant Melanoma and in Psoriasis Vulgaris . . 256

Onkologie-Mitteilungen 261

Bibliographischer Hinweis: Inhaltsverzeichnisse dieser Zeitschrift erscheinen regelmäßig in current contents ${ }^{\circledR}$ sowie in anderen bibliographischen Diensten. 